\title{
America's Forgotten Nuclear Waste Dump in the Pacific
}

\author{
Michael B. Gerrard
}

\begin{abstract}
During the Cold War the United States detonated sixty-seven nuclear weapons over the atolls of Bikini and Enewetak in the Marshall Islands. In the late 1970s the United States addressed the massive amount of residual contamination by abandoning Bikini as permanently uninhabitable and pushing much of the waste at Enewetak into the open lagoon. Much of the plutonium was dumped into the crater that had been left by an atomic bomb explosion, and then covered with a thin shell of cement. The resultant "Runit dome" sits unmarked and unguarded in a small island and one day will be submerged by the rising waters of the Pacific Ocean, unless it is first torn apart by typhoons. Radiation from the Marshall Islands has already been detected in the South China Sea. Using the experience of the Marshall Islands as a case study, this article seeks to shed light on the environmental and security challenges of nuclear waste disposal in the Pacific and beyond.
\end{abstract}

$\mathrm{T}$ he United States government has not had much luck in building new repositories for nuclear waste. It has abandoned plans for one in Yucca Mountain, Nevada, partly out of concern that it could not meet the standard of safely containing the radiation for one million years. ${ }^{1}$ A facility near Carlsbad, New Mexico, first opened in 1999, shut down after two accidents in February 2014.

However, little known even to many specialists in the field, the United States built a repository in the late 1970s, filled it with plutonium waste, and walked away. It has no signs, guards, or fences and it is on an island threatened by the rising seas. The site is in the Republic of the Marshall Islands, halfway between Hawaii and Australia.

This article recounts the origins of this repository, known as the Runit dome, the unsuccessful efforts of the people of the Marshall Islands to obtain adequate compensation for the losses they endured as a result of the nuclear testing program in their homeland, and the likely sorry future of the dome and of the nation. This saga stands as a parable of how the flow of modern history - a world war, a cold war, and a warming planet-have devastated a peaceful population that did nothing to deserve its successive tragedies.

Between 1946 and 1958, the United States exploded sixty-seven nuclear weapons in the Marshall Islands, chiefly the atolls of Bikini and Enewetak-

Michael B. Gerrard is Andrew Sabin Professor of Professional Practice and director of the Sabin Center for Climate Change Law at Columbia Law School, and associate chair of the Faculty of Columbia's Earth Institute. He is co-editor (with Gregory E. Wannier) of Threatened Island Nations: Legal Implications of Rising Seas and a Changing Climate (2013). 
each a thin, broken circle of coral reefs surrounding a lagoon, the remnants of an ancient volcano. In the 1970s, as the United States was preparing to grant independence to the Marshall Islands, it considered what to do about the mess that the nuclear testing had left behind.

Bikini was so radioactive that there was little hope of allowing its displaced population to return home in the foreseeable future. But the military studied how to reduce the radiation levels at Enewetak, the site of forty-four of the tests, so that at least some acreage could become habitable again. The bomb in one of these forty-four tests had misfired-only the high explosive was detonated, fragmenting the plutonium element and scattering it over a large area. Some of the debris from the explosion was immediately shoved into the lagoon to prepare the proving ground for another explosion twelve days later, but numerous plutonium-contaminated fragments were still scattered around the site. ${ }^{2}$

The United States considered several options for cleaning up Enewetak, ranging from simply covering the contaminated dirt with a blanket of clean soil to shipping it to disposal sites at home. The government chose to dump some of the waste into the crater left by one of the bombs, to shove some into the lagoon, and to leave some in place.

One of Enewetak's forty islands is called Runit. Nine of the nuclear tests had been there, and another nine on barges in the nearby lagoon. During one of the tests, the "Cactus test" held on May 5, 1958, a weapon roughly the size as the Hiroshima bomb left a crater that was three hundred and fifty feet in diameter and thirty feet deep. ${ }^{3}$ That seemed about the right size for the hottest waste that the United States wanted to dispose of. Never mind that the crater was below sea level at high tide, ${ }^{4}$ that the coral rock was naturally permeable, ${ }^{5}$ and that there had been three other nuclear detonations within three hundred feet, so the rock was highly fractured. ${ }^{6}$

The Department of Defense concluded that there was so much soil contaminated with radioactive cesium-137 and strontium-90 that moving it would result in severe ecological damage, so it would be allowed to decay naturally. ${ }^{7}$ Both have a half-life of about thirty years (though it might not be safe to live nearby for quite a bit longer than that). Other waste-such as various kinds of low-level radioactive materials - might be more manageable. But the plutonium-239 was of greatest concern. It has a half-life of twenty-four thousand years, and with enough of it in the right form, a bomb could be made. That is why, in an entirely different part of the world, the United States participated in a seventeen-year, $\$ 150$ million operation, completed in 2013, to secure and clean up a Soviet-era nuclear test site in Kazakhstan that is contaminated with plutonium. ${ }^{8}$

At Enewetak, the Defense Department decided to put as much plutonium as it could gather onto specially equipped landing craft and barges and dump it in the crater left by the Cactus test. ${ }^{9}$ Special attention was paid to the plutonium fragments that crews had picked off the ground and put in 437 plastic bags. ${ }^{10}$ There was some discussion of extracting high-grade plutonium from them, but ultimately they went into the crater as well. ${ }^{11}$ Most of the rest of the radioactive waste, with no or too little plutonium to trouble with, was bulldozed into the lagoon. ${ }^{12}$ 
The then-newly-formed Environmental Protection Agency (EPA) objected to disposal in the lagoon, but was overruled. ${ }^{13}$ The people of Enewetak and their attorney demanded total cleanup of the atoll and disposal of the material elsewhere; the United States spurned this suggestion as well, and selected a plan that would leave radiation at levels far higher than what is allowed after similar domestic cleanups. ${ }^{14}$

The idea of lining the bottom of the crater with cement was rejected because it would have been expensive and time-consuming and not deemed to provide any greater protection. Instead, when the cleanup was conducted from 1977 to 1979 , the material was pumped as a concrete slurry to the bottom of the crater. ${ }^{15}$ Oversized material that could not be ground into cement was shoved into the crater. ${ }^{16}$ A later study by the National Research Council found that these methods "were not fully successful," and left behind "unconsolidated... material that provide channels for water movement... at least part of the radioactivity contained in the structure is available for transport to the groundwater and, subsequently, to the lagoon." 17

In total, over 104,000 cubic yards of contaminated soil were placed in the crater, ${ }^{18}$ plus an undetermined amount of sand that was blown or washed into the crater by one of the several typhoons that hit during the construction. ${ }^{19}$ It was then all covered over with a cement dome. The cement was supposed to be eighteen inches thick, but some of it was as thin as twelve and a half inches. ${ }^{20}$ In all there are 357 concrete panels, placed without any internal reinforcing or expansion joints. The dome has a diameter of 367 feet and the containment area is 33 feet deep. ${ }^{21}$

The total cost of the cleanup of the atoll, such as it was, was $\$ 86.7$ million. Over four thousand US servicemen were assigned to work on the cleanup at one time or another. ${ }^{22}$ Six lost their lives in accidents (though none related to the radiation). ${ }^{23}$ An uncertain number of Marshallese also worked on the cleanup, often given no information about radiation safety. ${ }^{24}$ Despite repeated requests from the Marshall Islands government, these workers have been denied access to the Energy Employees Occupational Illness Compensation Program, as only US citizens are eligible-a bill to change that rule to include Marshallese died in the United States Senate in 2010. ${ }^{25}$

The cleanup was completed in 1979 and some of the residents of Enewetak-who had been forced out in 1946 to make way for the bombs-were allowed to return in 1980. It was not a return to their pre-nuclear homelands, however; about half the atoll was still uninhabitable and most of the remaining land had become unsuitable for growing food. ${ }^{26}$ Canned spam became a staple food the Marshall Islands, contributing to a national obesity and diabetes crisis. $^{27}$

Though the nuclear testing in the Marshall Islands ended in 1958, military testing there continues. In the 1960s the Department of Defense carried out Project Shipboard Hazard and Defense (SHAD), which involved spraying biological aerosols to test protective masks and other defensive measures for biological warfare. A weapons system on a navy ship disseminated various biological material over parts of Enewetak. Whether it was harmless is a contested matter. ${ }^{28}$ Enewetak was also a primary location in the 1960 s for the testing of intercontinental ballistic missiles and it was later used for test firing rocket 
motors. ${ }^{29}$ In 1971 and 1972, the air force conducted the Pacific Cratering Experiments to predict the impact of nuclear detonations upon strategic defense installations. A series of detonations of conventional explosive charges took place in Enewetak until a court halted it in $1972 . .^{30}$ And to this day, pursuant to the Compact of Free Association discussed below, the Ronald Reagan Ballistic Missile Defense Test Site operates on the Marshall Islands' atoll of Kwajalein. Intercontinental ballistic missiles are launched from Vandenberg Air Force Base in California to crash onto target sites on Kwajalein. ${ }^{31}$

\section{A Visit}

I was able to visit Runit in December 2010. I had been working with the Marshall Islands' government in studying the legal consequences of the threat that sea level rise poses to their national existence. There is no regular air service to Enewetak, but the week of my first visit to the country, there happened to be a special flight from the capital atoll of Majuro to take the US ambassador, the Marshall Islands' first lady, and other dignitaries to the dedication of a school in Enewetak that the United States had financed. ${ }^{32}$ The Marshall Islands government arranged for me to have a seat on the plane and then for me to be put on a small boat to cross the lagoon. (In fact, our flight was delayed because of the planned launch of a missile toward Kwajalein, where we were stopping to refuel.)

When the boat reached Runit, we jumped out, crossed a narrow beach, walked through some shrub brush, and saw the dome. There were no signs, fences, or guards. (A photo of a warning sign appears on the Internet, but it was not there when I visited.) My guide walked up the shallow incline of the dome and stood on its top; impulsively, I followed him to the top. I only stayed a minute or two; I wished I had a Geiger Counter. Had I not already known what it was, the origins and nature of this concrete structure-about twice the area of a football field - would have been completely mysterious.

From this low perch a few feet above sea level, the most prominent features are the twenty-three-mile-wide lagoon to the west ${ }^{33}$ the Pacific Ocean to the east $(2,724$ miles to Honolulu), and just a few hundred feet to the northeast, the almost-submerged crater from one of the other nuclear tests. In other words, as in most places in the Marshall Islands, what you see is mostly water.

\section{Radioactive Waste on the Home Front}

The United States government follows profoundly different procedures for disposal of radioactive waste at home than in the Marshall Islands. The Marshall Islands have no representation in Congress and no other source of political clout. Though certain executive orders call for the military to observe many of the US environmental laws when operating abroad, they were not in effect at the time of the creation of the Runit dome; and the nongovernmental organizations that have been so influential in ensuring the enforcement of environmental laws in the United States have no presence in the Marshall Islands. At home, 
US policy is to put nuclear waste in places where it cannot be released into the environment; in the Marshall Islands, the aim was far looser.

The government's original plan for the spent fuel from nuclear power plants was to reprocess it into new fuel, much as the French have been doing since $1966 .{ }^{34}$ (In most of the reset of the world, spent fuel is held in temporary storage areas awaiting the development of permanent repositories.) However, a nuclear weapon test in India in 1974 (using plutonium from a research reactor) led President Gerald Ford and President Jimmy Carter to abandon At home, US policy is to put nuclear waste in places where it cannot be released into the environment; in the Marshall Islands, the aim was far looser. this plan out of concern that the material would be susceptible to theft and that nuclear proliferation could result. (Concerns about non-state terrorism were not yet as prominent as they became in later years, especially after September 11,2001.)

To find a safe way to dispose of this material, in 1982 Congress enacted the Nuclear Waste Policy Act, which called for the permanent disposal of the spent fuel from nuclear power plants and other high-level nuclear waste in deep geologic repositories. An elaborate site selection study ensued, as did a great deal of politics, and in 1987, Congress selected Yucca Mountain, Nevada as the spot. ${ }^{35}$ The Department of Energy spent about $\$ 15$ billion on studies ${ }^{36}$ (including more than 450 boreholes to investigate the geology of the area ${ }^{37}$ ). The state of Nevada ferociously opposed this effort but lost all of the multiple lawsuits challenging it. However, in 2010, President Barack Obama cancelled the Yucca Mountain project, perhaps at the urging of the Democratic Senate Majority Leader, Harry Reid of Nevada, who was facing a tough reelection race. The president formed a blue ribbon commission to recommend a new plan for high-level radioactive waste (HLW). The resulting report called for continuing to store most of the HLW at the nuclear power plants where it was generated until a new site for a geologic repository was found and built; almost all such plants have spent fuel storage areas, many of which will need to be enlarged to hold the accumulating nuclear waste..$^{38}$ These areas keep the HLW in pools of water for at least five years until it cools down sufficiently to be placed in dry casks. ${ }^{39}$ Extreme care is taken to ensure that none of the radioactivity enters the outside environment.

Another type of radioactive waste is transuranic waste (TNU) - material that is heavier than uranium, and chiefly composed of plutonium. In 1999 the Waste Isolation Pilot Plant near Carlsbad, New Mexico opened and began accepting TNU. ${ }^{40}$ The permanent disposal takes place 2,100 feet underground in rooms mined from an ancient salt bed, designed to ensure that no radiation can leak out. As of this writing in March 2015, it has not yet reopened due to concern over the incidents mentioned earlier.

Much of the waste that is neither HLW nor TNU is classified as lowlevel radioactive waste (LLRW). To find places for the permanent disposal of LLRW, Congress in 1980 enacted the Low Level Radioactive Waste Policy Act and amended it in 1985. It required every state to come up with its own site for 
LLRW, either on its own or in concert with other states pursuant to an interstate compact. In 1992, the US Supreme Court invalidated as a violation of the Tenth Amendment the part of the statute that required states that did not build their own facility or join in a compact that built one to assume ownership of the LLRW generated within their borders. ${ }^{41}$ Meanwhile, private companies acquired land and obtained permits to build LLRW disposal facilities in Utah and, later, Texas. This eased the pressure on finding a governmentally-sited facility and, to date, no facilities sited pursuant to the federal statute have come even close to being approved. The private facilities are under close supervision designed to ensure no radioactive releases.

The domestic site for testing nuclear weapons was called the Nevada Proving Grounds, then the Nevada Test Site, and now (since 2010) the Nevada National Security Site. It is 1,360 square miles (larger than the state of Rhode Island) and was the scene of approximately one hundred detonations. The Department of Energy is in the midst of a complex, multi-decade process of cleaning up the site. Processing uranium ore to make nuclear fuel, nuclear weapons, and all other products leaves behind large quantities of waste material called "tailings." Tailings were long placed in immense outdoor piles from where wind and rain could spread the material, including low quantities of radiation, to surrounding areas. The Uranium Mill Tailings Radiation Control Act of 1978 is designed to remediate contaminated sites. This is carried out primarily by moving the waste into containment areas, covering it with compacted clay or other material, and topping it all with rocks or vegetation.

In sum, US policy displays a broad range of tolerance for the release of radiation into the environment. For HLW, TNU, and LLRW, zero releases are tolerable. For uranium mill tailings, there is a policy to halt the immediate releases and engage in long-term remediation. None of these laws comes anywhere close to condoning the bulldozing of large quantities of radioactively contaminated debris into a lagoon that is open to the ocean, as occurred in the Marshall Islands; they all call for secure storage or disposal in highly engineered structures.

\section{The Future of Runit}

Since the seas are rising, a natural question is what will become of the Runit dome. Longevity was not among the design criteria (unlike today's plans for facilities like Yucca Mountain) and the Defense Nuclear Agency found in 1981 some construction deficiencies "which could affect the durability of the crater portion of the structure." ${ }^{2}$ A task force of the National Research Council wrote in 1982 (long before sea level rise became a prominent issue), that "Probably the greatest hazard to the dome structure as well as to the people living on Enewetak Atoll will come from typhoons, which sometimes completely inundate these low islands. Although the dome was designed to withstand severe storm wave and typhoon activity, the typhoons in this part of the world are so severe that a series of these conceivably could cause breachment of the dome structure." 43 
However, not to worry. A 2013 report from the Department of Energy stated, "Catastrophic failure of the concrete dome facade covering the debris mount and instantaneous release of all its contents into the lagoon will not necessarily lead to any significant change in the radiation dose delivered to the local population." 44

The reason for this counterintuitive conclusion is shocking. The 2013 report found that the radiation inside the dome is "dwarfed" by the radiation in the sediments in the lagoon outside, ${ }^{45}$ thanks to the residue from the fortyfour nuclear tests over Enewetak. Thus the US agencies say that a leak from the dome would not cause environmental damage because it is dirtier on the outside than the inside. ${ }^{46}$

There is so much radiation in the sediments that it is spreading great distances. In February 2014, scientists looking for far-flung residue from the Fukushima nuclear accident found plutonium isotopes in the South China Sea that they traced through their atomic footprints to the Pacific Proving Grounds in the Marshall Islands. Some was old fallout, but they also found continuous transport of plutonium from the Marshall Islands along a feature of Pacific Ocean circulation called the North Equatorial Current, from a distance of about 2,800 miles. ${ }^{47}$ A lot of this fallout may be from the Enewetak and Bikini lagoons, but probably not Runit dome.

Nonetheless, Runit dome would not meet today's US standards for the disposal of ... Runit dome would not meet today's US standards for the disposal of household trash. household trash. The dome lacks any liner at the bottom, a secure cap on top, or a system to collect water, and is placed above fractured rock and next to the water and below sea level-a municipal landfill could not be built in such a way. ${ }^{48}$

At least some of the dome will probably be above water most of the time well into the next century. However, the ocean waters will wash over it with increasing frequency and in a few decades_-just when is not clear — at high tide the lower part of it will probably be submerged.

In 2011, Congress required the Department of Energy to undertake new inspections of Runit, and it did so in May and June 2013. ${ }^{49}$ The results show the concrete dome is deteriorating and the radioactive groundwater below rises and falls with the tides. ${ }^{50}$ Storms wash sand onto the dome and vines grow into the cracks. ${ }^{51}$ One day, the Runit dome will likely be submerged or torn apart by storms. ${ }^{52}$

\section{Legal Remedies}

After World War II, the Marshall Islands became a United Nations (UN) trust territory under the administration of the United States. In 1986, the United States and the Marshall Islands entered into the Compact of Free Association, under which the Marshall Islands would become an independent sovereign nation; the new Republic of the Marshall Islands (RMI) was admitted to the 
United Nations in 1991. The Compact provided for payment of $\$ 150$ million to RMI in compensation for the damages to the country and its citizens as a result of the nuclear weapons testing program and for the establishment of a Nuclear Claims Tribunal to determine the recipients and amounts of the payments.

The Tribunal held hearings for two years and decided that over $\$ 2$ billion in total damages that should be awarded. ${ }^{53}$ RMI presented a petition to Congress to increase the payments to meet the amount awarded by the Tribunal. ${ }^{54}$ Congress took no action. Lawsuits were instituted against the United States to compel payment, but the federal courts declared that they had no jurisdiction over the matter..$^{55}$ The United States Supreme Court refused to take the case, and RMI was left to continue to ask Congress to provide relief. This has been completely fruitless.

The US environmental statute that comes closest to providing relief is the Resource Conservation and Recovery Act. It allows persons at risk of "imminent and substantial endangerment" from hazardous waste to sue to compel a cleanup. However, the statute and EPA regulations contain detailed definitions of "hazardous waste" as covered by the statute, and it is not apparent that any of the material in Runit dome or the nearby lagoon falls within that definition.

At the international level, RMI is faring no better. At the Conference of the Parties (COP) to the United Nations Framework Convention on Climate Change (UNFCCC) in Copenhagen in 2009, the parties overwhelmingly accepted an objective of preventing global average temperatures from exceeding $2^{\circ} \mathrm{C}$ above pre-industrial conditions. RMI and the other low-lying island nations vigorously protested, since the scientific evidence suggests that at $2^{\circ} \mathrm{C}$, they would be entirely submerged in the next century and uninhabitable well before then; they demanded an objective of $1.5^{\circ} \mathrm{C}$. The $2^{\circ} \mathrm{C}$ goal has been repeatedly reaffirmed in the subsequent UN conferences, with a weak pledge to reevaluate in some subsequent year. A continuation of business-as-usual emissions growth would bring us to around $4^{\circ} \mathrm{C}$ by the end of the century. If the United States, China, and the European Union all carry out their current non-binding pledges, and if several other nations join in, we will probably be in the neighborhood of $3^{\circ} \mathrm{C}$ by the end of the century. ${ }^{56}$

The United Nations Human Rights Council has appointed a Special Rapporteur on Toxic Wastes. In 2012, the Special Rapporteur issued a report on his investigation of the legacy of nuclear testing in RMI. The report referenced Runit dome but made no recommendations as to it. ${ }^{57}$ Even if it had, the Human Rights Council has no power to compel the United States or other countries to take action.

In 2011 the Republic of Palau and RMI joined in an effort to seek an advisory opinion from the International Court of Justice (ICJ) in The Hague with respect to the obligations of the major developed nations to reduce their greenhouse gas emissions so that the small island nations do not drown. Under the United Nations Charter, this question could have been submitted to the ICJ upon a favorable vote of a majority of the members of the Untied Nations General Assembly. The United States actively opposed this effort and nowhere near the requisite number of votes could be obtained. 
One aspect of the Compact of Free Association that has been effective is the permission it granted the people of the Marshall Islands to immigrate to the United States. A steady stream of Marshallese are moving to the United States for the jobs, education and health care available here; of the nation's population of about sixty thousand, nearly ten thousand (both of these numbers are highly uncertain) live in northwestern Arkansas, centered around the factories of Tysons Foods, their largest employer. Almost the entirety of RMI has an elevation of about two meters above sea level on a calm day (and no place is more than three or four meters, thanks to the biology of coral reef formation). If the Runit dome stays intact, by the time it is underwater, so will be the rest of the Marshall Islands; its entire population will have had to flee for dry land. Thus there will be no nearby human neighbors of the dome, but its plutonium residue will be carried far by the ocean currents. There is probably no telling whether, when and where there will be sufficient concentrations to harm aquatic life and the people who depend on it.

\section{Conclusion}

The United States detonated sixty-seven nuclear weapons at the Marshall Islands. (More precisely it detonated sixty-six-one attempt failed, leading to a conventional explosive shattering the plutonium warhead and spraying fragments that were later collected in plastic bags.) Congress then failed to pay the compensation that the Congressionally-chartered Nuclear Claims Tribunal found should be paid. Today the cumulative greenhouse gas emissions of the United States (the largest single Runit dome stands-and eventually will sink-as a testament to the failure of US and international law to protect this vulnerable island nation from the devastation caused, first by the Cold War and now by the industrially-induced warming of the planet. contributor) and the other nations of the world are raising the seas and one day will almost certainly submerge all of the Marshall Islands.

Runit dome stands-and eventually will sink-as a testament to the failure of US and international law to protect this vulnerable island nation from the devastation caused, first by the Cold War and now by the industriallyinduced warming of the planet.

\section{Notes}

${ }^{1}$ US Environmental Protection Agency, Fact Sheet: Public Health and Environmental Radiation Protection Standards for Yucca Mountain, Nevada (40 CFR Part 197), Final Rule, EPA-HQOAR-2005-0083 (Washington, DC: United States Government Printing Office, 2008).

${ }^{2}$ Defense Nuclear Agency, The Radiological Cleanup of Enewetak Atoll, DARE\# 27293 (Washington, DC: Defense Nuclear Agency, 1981, 403.

${ }^{3}$ National Research Council, Committee on Evaluation of Enewetak Radioactivity Containment, Evaluation of Enewetak Radioactivity Containment, 019026391 (Washington, DC: National Research Council, 1982), 12. 
${ }^{4}$ Ibid.

${ }^{5}$ Ibid., 15.

${ }^{6}$ Ibid., 12.

${ }^{7}$ Radiological Cleanup of Enewetak, 85.

${ }^{8}$ Ellen Barry, "A Secret Race for Abandoned Nuclear Material," New York Times, August 18, 2013.

${ }^{9}$ Radiological Cleanup of Enewetak, 330.

${ }^{10}$ Ibid., 418.

${ }^{11}$ Ibid., 418, 443-4; Terry Hamilton, A Visual Description of the Concrete Exterior of the Cactus Crater Containment Structure, prepared by the Lawrence Livermore Laboratory, LLNLTR-648143 (2013), 8.

${ }^{12}$ Hamilton, Visual Description, 6.

${ }^{13}$ Radiological Cleanup of Enewetak, 94.

${ }^{14}$ Congressional Research Service, Republic of the Marshall Islands Changed Circumstances Petition to Congress, by Thomas Lum, et al. RL32811 (Washington, DC: Congressional Research Service, 2005), 26-29.

${ }^{15}$ Radiological Cleanup of Enewetak, 408, 428-31.

${ }^{16}$ Ibid., 431.

${ }^{17}$ Evaluation of Enewetak Radioactivity, 29.

${ }^{18}$ Radiological Cleanup of Enewetak, 441.

${ }^{19}$ Ibid., 428, 434; Evaluation of Enewetak Radioactivity, 16.

${ }^{20}$ Ibid., 15.

${ }^{21}$ Hamilton, Visual Description, 8.

${ }^{22}$ Ibid., 6; Radiological Cleanup of Enewetak, 500.

${ }^{23}$ National Research Council, Evaluation of Enewetak Radioactivity, 12; Hamilton, Visual Description, 6.

${ }^{24}$ Barbara Rose Johnston and Holly M. Barker, The Consequential Damages of Nuclear War: The Rongelap Report (California: Left Coast Press, 2008), 237.

${ }^{25}$ Tina Stege in discussion with the author; Statement of Nikolao I. Pula, Director, Office of Insular Affairs, before Senate Committee on Energy and Natural Resources Regarding S. 2941 Marshall Islands Supplemental Nuclear Compensation, May 19, 2010, http://www.energy.senate.gov/public/ index.cfm/files/serve?File_id=b13c8bc2-ff3f-2090-8291-450d9653ca3d; Johnson and Barker, Consequential Damages of Nuclear War, 237-238.

${ }^{26}$ Davor Pevec, "The Marshall Islands Nuclear Claims Tribunal: The Claims of the Enewetak People," Denver Journal of International Law and Policy 35 (2006-2007): 221, 229, 236; Holly Barker, Bravo for the Marshallese: Regaining Control in a Post-Nuclear, Post-Colonial World (Case Studies on Contemporary Social Issues) (Massachusetts: Cengage Learning, 2012), 37-38.

${ }^{27}$ Nick Squires, "Spam at heart of South Pacific obesity crisis," The Telegraph, April 12, 2008, http://www.telegraph.co.uk/news/worldnews/1578329/Spam-at-heart-of-South-Pacific-obesitycrisis.html; "Defeating Diabetes: A Story of Hope from the Marshall Islands," May 15, 2012, http://blog.alphaomegafood.com/defeating-diabetes-a-story-of-hope-from-the-marshallislands/.

${ }^{28}$ Giff Johnson, "Marshall Islands Chemical, Biological Tests Revealed," Marianis Variety, June 10, 2002, http://www.mvariety.com/community-bulletin-sp-595/7890--marshalls-chemicalbiological-tests-revealed; Nautilus Institute for Security and Sustainability, US Chemical and Biological Warfare Tests in the Pacific and Australia, http://nautilus.org/apsnet/us-chemical-andbiological-warfare-tests-in-the-pacific-and-australia/\#axzz3BN6oaiuo; National Academics, The Center for Research Information, Health Effects of Project SHAD Biological Agent: Bacillus Globighi, IOM-2794-04-001 (Silver Spring, MD: The Center for Research Information, Inc., 2004). ${ }^{29}$ Hamilton, Visual Description, 4.

${ }^{30}$ US Department of Energy, Enewetak Radiological Support Project: Final Report, NVO-213 (Nevada: United States Department of Energy, 1982), 16-18; GlobalSecurity.org, "Mine Throw," http://www.globalsecurity.org/wmd/ops/mine-throw.htm; Hamilton, Visual Description, 4.

31 "Minuteman III Missile Launch—California To Kwajalein Atoll," YouTube, 7:37, from official Air Force video (December 28, 2012), posted by Dziban Molniya, https://www.youtube.com/ 
watch?v=6SObYcIRTlI.

${ }^{32}$ Embassy of the United States Majuro Marshall Islands, "Ambassador Speeches 2010 Enewetak Elementary School Dedication Remarks," December 16, 2010, http://majuro.usembassy.gov/ sp_12162010.html.

${ }^{33}$ M. Atkinson, S. V. Smith and E. D. Stroup, "Circulation in Enewetak Atoll lagoon," Limnol. Oceanogr, 26(6) (1981), 1076, http://aslo.net/lo/toc/vol_26/issue_6/1074.pdf.

${ }^{34}$ Mycle Schneider and Yves Marignac, Spent Nuclear Fuel Reprocessing in France (A Research Report of the International Panel on Fissile Materials), April 2008, 2.

${ }^{35}$ State of Nevada v. Watkins, 939 F.2d 710 (9 $9^{\text {th }}$ Cir. 1991).

${ }^{36}$ US Government Accountability Office, Commercial Nuclear Waste: Effects of a Termination of the Yucca Mountain Repository Program and Lessons Learned, April 2011, 10.

${ }^{37}$ Margaret S.Y. Chu and J. Russell Dyer, "Licensing, Design, and Construction of the Yucca Mountain Repository," The Bridge 33 no. 3 (Fall 2003), 18.

${ }^{38}$ Blue Ribbon Commission on America's Nuclear Future, Department of Energy, Report to the Secretary of Energy, Washington, DC: US Department of Energy, 2012.

${ }^{39}$ Nuclear Regulatory Commission, "Spent Fuel Storage in Pools and Dry Casks: Key Points and Questions and Answers," March 12, 2015, http://www.nrc.gov/waste/spent-fuel-storage/ faqs.html.

${ }^{40}$ Richard B. Stewart and Jane B. Stewart, Fuel Cycle to Nowhere: US Law and Policy on Nuclear Waste (Tennessee: Vanderbilt University Press, 2011), 62.

${ }^{41}$ New York v. United States, 505 U.S. 144 (1992).

${ }^{42}$ Radiological Cleanup of Enewetak, 470.

${ }^{43}$ Evaluation of Enewetak Radioactivity, 28.

${ }^{44}$ Hamilton, Visual Description, 1; Evaluation of Enewetak Radioactivity, 1.

${ }^{45}$ Hamilton, Visual Description, 14; Hamilton, Visual Description, 10.

${ }^{46}$ Victor E. Noshkin and William L. Robison, "Assessment of a Radioactive Waste Disposal Site at Enewetak Atoll" Health Physics 73:1 (July 1997), 234, 246; Hamilton, Visual Description, 1.

${ }^{47}$ Junwen Wu, et al., "Isotopic Composition and Distribution of Plutonium in Northern South China Sea Sediments Revealed Continuous Release and Transport of Pu from the Marshall Islands," Environmental Science \& Technology, 48 no. 6 (2014): 3136-3144.

${ }^{48}$ New York State Law, Pub. L. No. 6 NYCRR, Subpart 360-1 (1988).

${ }^{49}$ Embassy of the United States Majuro Marshall Islands, "Press Release United States Department of Energy Completes First Mission to Enewetak Atoll to Being Long-Term Special Studies of Runit Dome," June 7, 2013, http://majuro.usembassy.gov/doe_runit_dome.html.

${ }^{50}$ Hamilton, Visual Description, 2-3, 14, 22, 41.

${ }^{51}$ Ibid., 10, 11.

${ }^{52}$ Ibid., 15.

${ }^{53}$ Embassy of the United States Majuro, Marshall Islands, "The Legacy of U.S. Nuclear Testing and Radiation Exposure in the Marshall Islands," http://majuro.usembassy.gov/legacy.html.

${ }^{54}$ Republic of the Marshall Islands Changed Circumstances Petition to Congress.

${ }^{55}$ People of Bikini v. United States, 554 F.3d 996 (Fed.Cir. 2009). cert. den. 554 U.S. 1048 (2010). ${ }^{56}$ Bill Hare et al., "China, US and EU Post-2020 Plans Reduce Projected Warming," December 8, 2014, http://climateactiontracker.org/assets/publications/briefing_papers/CAT_Briefing_10122014.pdf.

${ }^{57}$ United Nations General Assembly Human Rights Council, United Nations General Assembly, Report of the Special Rapporteur on the Implications for Human Rights of the Environmentally Sound Management and Disposal of Hazardous Substances and Wastes, A/HRC/21/48/Add.1 (New York: United Nations, 2012), http://www.ohchr.org/Documents/HRBodies/HRCouncil/ RegularSession/Session21/A-HRC-21-48-Add1_en.pdf. 